\title{
Evaluation of bat-related knowledge, perceptions, and practices in an urban community: A strategy for Conservation Biology and health promotion
}

\section{Norlan de Jesus Santos ${ }^{1, *}$, Elen Santos da Paz $^{2}$, Ianei de Oliveira Carneiro $^{1}$ and Carlos Roberto Franke ${ }^{1}$}

${ }^{1}$ School of Veterinary Medicine and Zootechnics. Postgraduate Program in Animal Science in the Tropics. Federal University of Bahia. Ondina. Salvador-BA, Brazil (CEP 40170-115).*Email: norlansantos@hotmail.com.

${ }^{2}$ Superintendence of Heritage from the State of Bahia. Administrative Center of Bahia. Salvador-BA, Brazil (CEP 41745-002).

\begin{abstract}
The aim of this ethnozoological study was to identify variables related to knowledge, perceptions, and practices associated with the occurrence of bats in an urban area. We carried a retrospective observational study with residents of 31 cases and 178 control households. We defined the cases as households where accidents occurred from 2012 to 2015, according to official health records. The control households have no accident record in the same area. We conducted data collection through a semi-structured questionnaire and performed descriptive analyses and proportion (chi-square) to identify differences between the responses of cases and controls. We have identified important gaps in relation to basic knowledge, good practices, and the importance of bats to public health. These findings should be targeted for intervention and correction by environmental educators and health managers aimed at reducing the risk of accidents with bats and zoonosis, mainly rabies.
\end{abstract}

Keywords: Ethnozoology; Conservation; Zoonosis prevention; Health promotion.
Received June 10, 2019

Accepted July 15, 2019

Available online July 18, 2019

Released August 31, 2019

Full Text Article

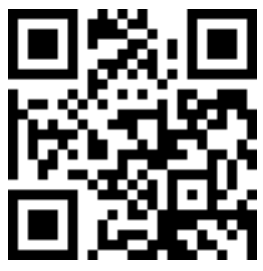

ORCID

D) 0000-0002-3146-7813 Norlan de Jesus Santos

(1) 0000-0002-0650-9049 Elen Santos da Paz

(1) 0000-0003-0375-8506 Ianei de Oliveira Carneiro

(ㄱ) 0000-0002-3922-8526 Carlos Roberto Franke 


\section{Introduction}

The urbanization process has an influence on the composition and structure of bat communities because of changes in the natural environment (Hourigan et al., 2006; Threlfall et al., 2011, 2012; Jung et al., 2012). This process leads native species to present synanthropic habits, such as exploring the sources of food and shelter in the urban environment (Il'in et al., 2003; Evelyn, 2004).

In Brazil, are known nine families, 68 genera and 178 species of bats, with diverse eating and behavioral habits including the only three hematophagous species in the world and unique in Latin America: Desmodus rotundus, Diaemus youngi and Diphylla ecaudata (Nogueira et al., 2014). The proximity of bats to humans and domesticated animals can increase the chances of occurrence of accidents (Delpietro et al., 1994; Bredt et al., 1999).

Bats are related among the main agents that maintain and transmit zoonosis and figure like being recognized as reservoir hosts for viruses which can cross species barriers (i.e. spillover) to infect humans and other domestic and wild mammals. Despite the negative public's perception of bats, they are critical elements of biotic communities. They play important ecological functions, such as pollination, insect predation, and seed dispersal (Kalko, 1995; Cleveland et al., 2006; Novaes and Nobre, 2009; Kunz et al., 2011; Moosman et al., 2012).

In the last decade increased the number of studies worldwide evaluating the knowledge, perception, and practices adopted in the identification, prevention, and control of zoonosis, including those resulting from bat accidents (Liesener et al., 2006; Sexton and Stewart, 2007; Robertson et al., 2011; Moran et al., 2015; Rübsamen et al., 2015; Lu et al., 2016). In Brazil, these types of studies addressing the involvement of bats are still scarce (Esbérard et al., 1996; Bruno and Kraemer, 2010; Gomes et al., 2013), despite the contribution which can provide for their interdisciplinary character, relating cultural aspects to the promotion of human, animal and environmental health, according to the concept of One Health.

The aim of the present ethnozoological study was to identify variables related to the knowledge, perception, and practices of the population associated with bats in an urban community that presented accidents (scratches/bites) involving human caused by these animals.

\section{Materials and methods}

\section{Study area and definition of cases and controls}

During the months of April to July 2016, we carried a retrospective observational study of the case-control in the Sanitary District of Centro Histórico of the Municipality of Salvador (HCS). We used the unit of 'sanitary district' because the actions carried out by the Municipal Health Secretary of Salvador (Bahia State, Brazil) use this geographical subdivision of the county composed of 12 sanitary districts (SD). The HCS has a population of 77,721 inhabitants (Brasil, 2010). The HCS presents a low population density because of its history of occupation, with a predominance of houses and low buildings, some changed for use by the public administration and commercial activities. At present, several properties remain closed or in ruins. In the last forty years, the socioeconomic profile of the inhabitants of the HCS has changed. The residents present low income, and the area shows substantial dilapidation in the structure of buildings/houses and a devaluation and loss of quality in the urban infrastructure and cultural equipment (Bahia, 2014). We chose HCS as the study area because of the high number of accidents involving bats registered in national notifiable diseases information system (SINAN) 
along of the historical series from 2012 to 2015 analyzed in this study. The records in SINAN of the occurrences of bat accidents (bites/scratches) have the compulsory notification for the actions of rabies prevention and control.

In this study, the cases $(n=31)$ obtained in SINAN, referring to the period from 2012 to 2015, were defined as the residences with records of accidents caused in humans by bats. These records do not include the identification or description of the species of bats involved in the accidents. The controls selected were households with no record of accidents near the cases. For each case, we selected six controls and considered a level of significance $(\alpha)$ of 0.05 . The number of households for the calculation of the sample size was defined by a ratio between the number of inhabitants of the Historic Center of Salvador $(77,721$ individuals), available in the Superintendency of Economic and Social Studies of Bahia (Bahia, 2014) by the mean number of residents per household (3.4 individuals) identified by the census survey carried out by Brazilian Institute of Geography and Statistics (Brasil, 2010).

\section{Data collection}

We collected using a semistructured, interviewer-administered, paper-based questionnaire on active knowledge, perception, and practices associated with bats. Within each selected household, we selected one adult $\geq 18$ years of age to respond to an individual survey. The questionnaires were filled by the same researcher and retrieved daily. We entered data and analyzed using Epi-Info ${ }^{\mathrm{TM}} 7$ and reported as frequencies and percentages. The questionnaire included sections to capture information about knowledge, perception and practices following categories: (1) knowledge about sources of food for bats; (2) ecological role of bats; (3) association of bats with some disease; (4) bats sheltered at home; (5) location where the bats are living in the historic center of Salvador and (6) source of information about bats in the last decade. About the perception we to observe the following categories: (1) bat conservation in the urban environment; (2) visualization of bats over time in the HCS (for people who have lived for over 10 years at HCS); (3) presence of bats at residence; (4) bats definition and (5) bats active signs. We also asked participants to describe the hypothetical practices associated with the bats in the following situations: (1) after to identify bats sheltered at home; (2) after seeing a dead bat in peridomicile and (3) after a bat bite. In a complementary, the questionnaires presented open questions about diseases associated with bats.

\section{Statistical analysis}

The completed questionnaire was double-typed in the Epi Info Program. In addition, we compared the databases (data compare) to identify inconsistencies between the information presented in the databases and in the physical documents (questionnaires).

We summarized responses using descriptive statistics. The chi-square test or Fisher's exact test were used to perform the univariate analyses to compare the categorical data to identify the differences between the answer of cases and controls residents. A p $<0.05$ was significant.

\section{Ethical approval}

All procedures performed in studies involving human participants were under the ethical standards of the institutional research committee and with the 1964 Helsinki Declaration and its later amendments or comparable ethical standards. The Research Ethics Committee of the Federal University of Bahia, Salvador, Brazil approved the protocol.

\section{Informed consent}

All participants were informed of the study's purpose and assured that 
their responses would be kept anonymous. We obtained oral consent to ensure anonymity and accommodate illiterate participants.

\section{Results}

As described, we applied the questionnaires in all 31 cases households and 178 controls households. Most of the case households (29.93\%) and 114 (64\%) control households had only residential use. 64 (36\%) of controls household controls had residential and commercial use. The average residence time of the individuals was 17 and 24 years between cases and controls, respectively.

Bats visualization in the HCS area was informed by $90 \%(28 / 31)$ of the residents in the case households, and $41 \%(74 / 178)$ by residents in the control households (Table 1 ).

Table 1. Knowledge cited about bats among case and control households at the community study site, Salvador, Brazil.

\begin{tabular}{|c|c|c|c|}
\hline Variable & \multirow{2}{*}{\multicolumn{3}{|c|}{ No. $(\%)$}} \\
\hline Sources of food for bats & & & \\
\hline Insects & $10(32)$ & $66(37)$ & 77 \\
\hline Blood & $16(51)$ & $99(55)$ & 115 \\
\hline Fruits*** & $22(70)$ & $59(33)$ & 81 \\
\hline Nectar/flower & $0(0)$ & $0(0)$ & 0 \\
\hline Meat (ex:little rats) & $2(6)$ & $20(11)$ & 22 \\
\hline \multicolumn{4}{|l|}{ Ecological role of bats } \\
\hline Predation & $4(12)$ & $18(10)$ & 22 \\
\hline Pollination & $1(3)$ & $3(1)$ & 4 \\
\hline Seed dispersal & $4(12)$ & $20(11)$ & 24 \\
\hline Don't know & $22(70)$ & $137(79)$ & 159 \\
\hline \multicolumn{4}{|c|}{ Association of bats with some disease } \\
\hline Yes*** & $19(61)$ & $161(90)$ & 180 \\
\hline No & $11(36)$ & $8(4)$ & 19 \\
\hline \multicolumn{4}{|l|}{ Bats sheltered at home } \\
\hline Yes & $2(6)$ & $4(2)$ & 6 \\
\hline No & $29(93)$ & $174(97)$ & 203 \\
\hline \multicolumn{4}{|c|}{ Location where the bats are living in Historic Center of Salvador } \\
\hline Woods & $12(38)$ & $75(42)$ & 87 \\
\hline Church & $12(38)$ & $86(48)$ & 98 \\
\hline Abandoned houses ${ }^{* * *}$ & $22(70)$ & $55(30)$ & 77 \\
\hline Attic & $1(3)$ & $3(1)$ & 4 \\
\hline Don't know & $3(9)$ & $0(0)$ & 3 \\
\hline \multicolumn{4}{|c|}{ Source of information about bats in the last decade } \\
\hline Television & $16(53)$ & $63(35)$ & 79 \\
\hline Radio & $0(0)$ & $3(1)$ & 3 \\
\hline Health agents & $8(25)$ & $0(0)$ & 8 \\
\hline Internet & $4(12)$ & $19(10)$ & 23 \\
\hline Neighbors*** & $11(35)$ & $13(7)$ & 24 \\
\hline Popular knowledge & $5(16)$ & $39(21)$ & 44 \\
\hline
\end{tabular}

*** Difference statistically significant between cases and controls responses.

$(-)$ Lower than $1 \%$. 
However, when the frequency of visualization was evaluated, a reduction was identified over the last ten years. 20 $(65 \%)$ of residents in case households reported that visualization was more intense earlier, and there were significant differences among the study variables between groups.

We identify significant differences between case and control households regarding the perception of the residents who consider bats in the residence as negative. $91 \% \quad(162 / 178)$ of the respondents of control households have made a negative association related to bats in the residence. $20 \%(4 / 31)$ of the respondents of case households have made a positive association related to bats in the residence.

When we analyzed the total of respondents (209) in this study, 158 $(75 \%)$ consider the bat conservation in an urban environment a neutral or negative activity to the perpetuation of the human population. 51 respondents consider the bat conservation in an urban environment a positive activity. Of these, 12 (38\%) were case households residents and 39 (21\%) were control households (Table 2).

Table 2. Perception cited about bats among case and control households at the community study site, Salvador, Brazil.

\begin{tabular}{|c|c|c|c|}
\hline \multirow{2}{*}{ Variable } & Cases $(n=31)$ & Controls $(n=178)$ & Total \\
\hline & \multicolumn{2}{|c|}{ No. (\%) } & \\
\hline \multicolumn{4}{|c|}{ Bat conservation in an urban environment } \\
\hline Negative & $14(45)$ & $106(59)$ & 120 \\
\hline Positive & $12(38)$ & $39(21)$ & 51 \\
\hline Neutral & $5(16)$ & $33(18)$ & 38 \\
\hline \multicolumn{4}{|c|}{ Visualization of bats over time in the HCS (residents that live over than ten years)** } \\
\hline Higher before ${ }^{* * *}$ & $20(65)$ & $139(85)$ & 159 \\
\hline Higher now & $8(28)$ & $48(26)$ & 59 \\
\hline \multicolumn{4}{|c|}{ Presence of bats at the residence } \\
\hline Negative*** & 27 (77) & $162(91)$ & 186 \\
\hline Positive & $4(12)$ & $5(2)$ & 9 \\
\hline Neutral & $3(9)$ & $9(5)$ & 12 \\
\hline \multicolumn{4}{|l|}{ Bats definition } \\
\hline Mammals & $15(48)$ & $58(32)$ & 73 \\
\hline Rats with wings & $3(1)$ & $58(32)$ & 61 \\
\hline Rodents & $10(32)$ & $45(25)$ & 55 \\
\hline Birds & $1(3)$ & $11(6)$ & 12 \\
\hline Insect & $0(0)$ & $2(1)$ & 2 \\
\hline Mammals birds & $0(0)$ & $1(<1)$ & 1 \\
\hline Like a buterfly & $0(0)$ & $1(<1)$ & 1 \\
\hline Bats & $0(0)$ & $1(<1)$ & 1 \\
\hline Like a Snake/cats & $1(3)$ & $1(<1)$ & 2 \\
\hline Strange animal & $1(3)$ & $0(0)$ & 1 \\
\hline Don't know & $1(3)$ & $0(0)$ & 1 \\
\hline \multicolumn{4}{|l|}{ Bats active signs } \\
\hline Feces & $10(32)$ & $2(1)$ & 12 \\
\hline Dead bats & $3(9)$ & $5(2)$ & 8 \\
\hline Colony of bats & $1(3)$ & $2(1)$ & 3 \\
\hline Bats flying inside home*** & $23(74)$ & $25(14)$ & 48 \\
\hline Bats eating inside home & $2(6)$ & $2(1)$ & 4 \\
\hline
\end{tabular}

*** Difference statistically significant between cases and controls responses.

(-) Lower than $1 \%$. 
Table 3. Practices associated with bats among case and control households at the community study site, Salvador, Brazil.

\begin{tabular}{|c|c|c|c|c|}
\hline \multirow{2}{*}{$\begin{array}{l}\text { Practice } \\
\text { Adopted practice after to ident }\end{array}$} & \multicolumn{2}{|c|}{$\begin{array}{c}\text { Cases }(n=31) \\
n(\%)\end{array}$} & \multicolumn{2}{|c|}{$\begin{array}{c}\text { Controls }(n=178) \\
n(\%)\end{array}$} \\
\hline & \multicolumn{4}{|c|}{ Adopted practice after to identify bats sheltered at home } \\
\hline Hunting bats (to kill, not eat) & 4 & $(12)$ & 80 & $(44)$ \\
\hline Remove & 11 & $(35)$ & 59 & (33) \\
\hline Contact Zoonosis Center Control (ZCC) & 9 & $(29)$ & 11 & $(6)$ \\
\hline Nothing & 5 & $(16)$ & 7 & (3) \\
\hline Close access to prevent bat entry & 1 & $(3)$ & 1 & (3) \\
\hline Petting & 0 & $(0)$ & 1 & $(-)$ \\
\hline Apply poison/insecticide & 0 & $(0)$ & 2 & (1) \\
\hline leave the house (momentarily) & 0 & $(0)$ & 1 & $(-)$ \\
\hline Seek rabies post exposure prophylaxis & 0 & $(0)$ & 1 & $(-)$ \\
\hline Not informed & 1 & (3) & 15 & $(8)$ \\
\hline Total of respondents & 31 & & 178 & \\
\hline \multicolumn{5}{|c|}{ Practice adopted after see a dead bat in peridomicile } \\
\hline Throw the bat in the trash & 28 & $(100)$ & 163 & $(94)$ \\
\hline Bury the bat & 0 & $(0)$ & 4 & $(2)$ \\
\hline Contact Zoonosis Center Control (ZCC) & 0 & $(0)$ & 3 & (1) \\
\hline Contact Federal Environmental Agency & 0 & $(0)$ & 1 & $(-)$ \\
\hline Isolate the place & 0 & $(0)$ & 1 & $(-)$ \\
\hline Throw hot water with salt. & 0 & $(0)$ & 1 & $(-)$ \\
\hline Total of respondents & 28 & & 176 & \\
\hline \multicolumn{5}{|l|}{ Theoretical actions after bat bite $¥$} \\
\hline Seek basic medical care & 16 & $(53)$ & 92 & $(51)$ \\
\hline Seek a Hospital & 10 & $(33)$ & 69 & (38) \\
\hline Seek a Doctor & 2 & $(6)$ & 10 & $(5)$ \\
\hline Contact Zoonosis Center Control (ZCC) & 1 & (3) & 2 & (1) \\
\hline Self-medication & 1 & (3) & 1 & $(-)$ \\
\hline Not informed & 0 & $(0)$ & 3 & (1) \\
\hline Total of respondents & 30 & & 177 & \\
\hline
\end{tabular}

$¥$ hypothetical bat-accidents with the respondent or another person.

(-) Lower than $1 \%$.

$22(70 \%)$ of case households residents and $55(30 \%)$ of control households residents reported abandoned houses in the study area as the main shelters used for bats. There were significant differences between groups that cited the use of this shelter. 98 respondents cited the churches as a harborage for bats in the study area, of these $12(38 \%)$ were case households residents and $86(48 \%)$ were control households residents. $2(6 \%)$ residents in case households and $4(2 \%)$ control households residents cited the current presence of bats sheltered inside the domiciles.
Regarding the source of knowledge about bats, 79 residents cited television and 44 cited popular knowledge as the main source of information. Health agents were cited by $8(25 \%)$ case households residents and were not cited by control households residents.

When asked about the definition of a bat, $15(48 \%)$ of the residents in the case households and $58(32 \%)$ in the controls referred to bats as mammals. 10 (32\%) case households residents defined bats as rodents and $58(32 \%)$ of the control households residents defined the bats as "rats with wings". 
Of the 209 respondents, 20 $(10 \%)$ cited the attitude of contacting the Zoonosis Control Center (ZCC) to remove a bat living inside domicile. $3(<1 \%)$ residents related to contacting the $\mathrm{ZCC}$ in the case to find a dead bat in the peridomicile. The most frequent practice in the case to identify a bat living inside the domicile was to kill the animals. 88 (40\%) respondents cited this action. Removing the bats by the residents itself (throw in the trash) was cited by 70 (33\%) respondents (Table 3 ).
$124(60 \%)$ of the 209 respondents did not know to associate the bats with diseases. Of these, 7 (5\%) were residents of case households and $117(65 \%)$ were residents of control households. 58 (28\%) residents cited rabies as a disease transmitted by bats. Among these, 11 (35\%) were case households residents and 47 (26\%) were control households residents. 9 (29\%) case households residents and $5(2 \%)$ control households residents believe that bats are not involved in the transmission of disease (Table 4).

Table 4. Diseases associated with bats cited among case and control households at the community study site, Salvador, Brazil.

\begin{tabular}{lccccc}
\hline Disease & Cases $(\mathbf{n = 3 1 )}$ & $\mathbf{( \% )}$ & Controls $(\mathbf{n = 1 7 8})$ & $\mathbf{( \% )}$ & Total \\
\hline Don't know*** & 7 & $(5)$ & 117 & $(65)$ & 124 \\
Rabies & 11 & $(35)$ & 47 & $(26)$ & 58 \\
No disease & 9 & $(29)$ & 5 & $(2)$ & 14 \\
Disease of feces & 0 & $(0)$ & 5 & $(2)$ & 5 \\
Fever & 1 & $(3)$ & 2 & $(1)$ & 3 \\
Skin diseases & 0 & $(0)$ & 2 & $(1)$ & 2 \\
Infection & 1 & $(3)$ & 1 & $(-)$ & 2 \\
Hepatitis & 0 & $(0)$ & 1 & $(-)$ & 1 \\
Itches and blemishes & 0 & $(0)$ & $-)$ & 1 \\
\hline
\end{tabular}

***Difference statistically significant between cases and controls responses.

(-) Lower than $1 \%$.

\section{Discussion}

We surveyed a community in Northeast Brazil to determine the knowledge, perception, and practices regarding bats. Although bats play key roles in ecological and public health, these types of studies addressing bats are still scarce. Efforts to implement and improve bat management interventions to reduce urban accidents have been hampered by the lack of epidemiologically based information that allows identification of best strategies using environmental education. Our study indicates a large proportion of lack of information, poor perception, and inappropriate practices, regarding bat and can be useful to guide the interventions for policymakers and environmental educators.

We observed a significant difference among case households residents when compared to controls in relation to the visualization of bats flying at home. It is possible that, because of having already had an accident episode, case households residents are more attentive to bats at home. In addition, these residents become more tolerant because they have been informed that these are usually non-hematophagous bats (Sexton and Stewart, 2007; Gomes et al., 2013; Lu et al., 2016). This result is reinforced because the major part of case household residents reported that bats 
eat fruit compared to controls households residents. A study performed in another urban area found similar results (Esbérard et al., 1996), so we believe our findings are plausible and consistent. The presence of frugivorous bats in urban environments is common (Bredt et al., 1998; Mickleburgh et al., 2002; Reis et al., 2002; Zanon et al., 2007; Pacheco et al., 2010) and play an important role for the permanence of plant species in the urban environment (Souza et al., 2006).

Most case households have a residential use only and with the permanence of the inhabitants in the nocturnal period when the bats usually present greater activity. Intensification of bat activity at night is well documented (Hayes, 1997; Kuenzi and Morrison, 2003; Milne et al., 2005; Brooks, 2009) and corroborates the previous study where there was a higher incidence of accidents during the night (Liesener et al., 2006).

28 (90\%) case households residents cited the visualization of flying bats in HCS. However, is important to cite, considering the total of 159 respondents that lived over ten years in the HCS, related the diminish of visualization along of the last decade. This may result from the behavior of bats to avoid areas with human activity (Liesener et al., 2006) and the revitalization of HCS, with the improvement of residences, which may contribute to reducing the availability of food (ex: insects), shelters and as a result of the revitalization works in the area (Bahia, 2014). 70\% of the case households residents cited abandoned houses as the main refuge used by bats in the study area. This result is consistent with the presence of numerous abandoned houses or in ruins in the HCS (Bahia, 2014). This result corroborates studies in urban areas that identified the greater activity of bats where there is fewer human activity (Liesener et al., 2006).
Although bats play a key role in the ecosystem (Cleveland et al., 2006; Kunz et al., 2011; Moosman et al., 2012), overall 209 respondents, 50 (23\%) associated the bats in the urban area with predation, pollination, and seed dispersal. Our findings demonstrate the lack of knowledge regarding the important role that bats play in nature.

Overall, 209 respondents, 158 $(70 \%)$ were neutral or opposed to bats conservation in the urban environment. This result evidences the lack of knowledge regarding the ecological activities performed by bats, as identified in the present study. This result is similar to the assessment that identified the negative association related to bats (Bjerke and Østdahl, 2004; Prokop and Tunnicliffe, 2008). This negative association in relation to bats is identified even after the use of teaching method on the group followed by assessment through written tests (Bruno and Kraeme et al., 2010). Our findings are consistent because bats are characterized by forming a stigmatized group (Lu et al., 2016).

The main media to acquiring information about bats was the communication among neighbors, cited by $11 \quad(35 \%)$ residents in case households and presented a significant difference compared to the controls. This result probably is because of the need for readily available information after the accident with bats. Television was the most cited media as a bat information provider. This data reinforces the need to use television as the main media to disseminate this knowledge, especially given the fact that official data indicate television in over $95 \%$ of households in Salvador (Brasil, 2010). Our results highlight the low participation of the radio, as well as the health agents in the dissemination of information to the population, pointing out the need to improve health communication strategies with the population.

The most common practice when identifying bats living at home was to kill, 
which also demonstrate the negative aspect associated with bats in the urban environment (Bruno and Kraemer et al., 2010). In addition, the practice most used to find the dead bat in the peridomicile was to throw in the trash. Both practices are inadequate and there is the possibility of the person having contact with the bat's fluids and suffering an accident (scratch/bite). However, our results suggest that the bat's accidents are taken seriously by almost all the interviewees, considering the attitude of seeking a health post, hospital or doctor because of a bats accident. This result corroborates evidence found in studies that identified the public health care system plays an essential role in diagnosis and rabies prevention (Liesener et al., 2006; Moran et al., 2015).

The small number of respondents stated that they would communicate to the ZCC the cases of presence of bats living or dead at home and the most reported practice is to throw into the trash. This practice elevates the risk of accidents or disease transmission to intensify the possible contact with bat's fluids and by the fact that domiciled animals may have access to bats in the trash (Delpietro et al., 1994; Phillips et al., 2001; Woods et al., 2003). In addition, these practices result in underreporting of the rabies cases and hinder the epidemiological surveillance of these events.

When asked about a hypothetical involvement of bats in the transmission of some disease, 58 associated bats with rabies. Of these, 11 (35\%) were case households residents and 47 (26\%) were control households residents. This difference is probably because the accident acted as a stimulus to the search for information about possible diseases associated with bats. It is surprising that $16(11 \%)$ interviewed in the case households did not associate bats with the transmission of zoonoses. This result is similar to that found in an assessment of the knowledge of individuals with a history of bats accidents that did not associate the possibility of transmission of zoonoses by bats (Robertson et al., 2011).

There are limitations in our study that should be noted. First recruiting participants only in an area is possible to have a geographical influence that might have been imparted on the results observed. Finally, our findings may have been subject to reporting bias, since the case households residents may have been guided by the members of the health system because of the occurrence of accidents (scratches/bites), improving the knowledge that favors a better perception and more appropriate practices regarding bats. In this case, we believe that the gaps found in the present study may be even greater in area with no accidents involving bats.

\section{Conclusion}

Environmental education is a key strategy for preventing accidents with bats and rabies (Kotait et al., 1998). In Brazil, although the decreasing incidence of human rabies demonstrates the effectiveness of control actions, our results demonstrate the need to raise public awareness of the potential risk of rabies associated with bats exposures in urban areas. We identified gaps in relation to basic knowledge, perception, appropriate practices and the importance of bats for public health. These findings have the potential to be incorporated into corrective strategies and intervention measures developed by policymakers, health agents and environmental educators at reducing the risk of bats accidents and the transmission of zoonosis.

\section{Acknowledgments}

The authors thank all residents who participated in the survey and the municipal Zoonosis Control Center (ZCC) in Salvador, Bahia, Brazil. Additionally, we would like to thank FAPESB (Fundação de Amparo à Pesquisa da 
Bahia) for the financial support for the first author (NJS).

\section{Conflicts of interest}

Authors declare that they have no conflict of interests.

\section{Referências}

Bahia. Plano de Reabilitação Participativo: Avanços. Salvador: Companhia de Desenvolvimento Urbano do Estado da Bahia, Centro Antigo de Salvador, 2014.

Bjerke, T.; Østdahl, T. Animal-related attitudes and activities in an urban population. Anthrozoös, v. 17, no. 2, p. 109-129, 2004. https://doi.org/10.2752/ 089279304786991783

Brasil. Instituto Brasileiro de Geografia e Estatística. Censo Demográfico. 2010. Available from: <http://www.censo2010. ibge.gov.br/resultados.html>. Accessed on: Apr. 23, 2019.

Bredt, A.; Araújo, F. A. A.; Caetano Júnior, J.; Rodrigues, Ma. G. R.; Yoshizawa, M.; Silva, M. M. S.; Harmani, N. M. S.; Massunaga, P. N. T.; Bürer, S. P.; Porto, V. A. R.; Uieda, W. Morcegos em áreas urbana $\mathrm{e}$ rurais: manual de manejo e controle. Brasília: Fundação Nacional de Saúde, 1998.

Bredt, A.; Uieda, W.; Magalhães, E. D. Morcegos cavernícolas da Região do Distrito Federal, Centro-Oeste do Brasil (Mammalia, Chiroptera). Revista Brasileira de Zoologia, v. 16, no. 3, p. 731-770, 1999. https://doi.org/10.1590/S0101-

81751999000300012

Brooks, R. T. Habitat-associated and temporal patterns of bat activity in a diverse forest landscape of Southern New England, USA. Biodiversity and Conservation, v. 18, no. 3, p. 529-545, 2000. https://doi.org/10.1007/ s10531-008-9518-x

Bruno, M.; Kraemer, B. M. Percepções de estudantes da $6^{\underline{a}}$ série (7ํㅜ ano) do "Ensino Fundamental" em uma escola pública de Belo Horizonte, MG sobre os morcegos: uma abordagem etnozoológica. e-Scientia, v. 3, no. 2, p. 42-50, 2010. Available from: <https://revistas.unibh.br/dcbas/article/vie w/169>. Accessed on: Apr. 23, 2019.
Cleveland, C. J.; Betke, M.; Federico, P.; Frank, J. D.; Hallam, T. G.; Horn, J.; Kunz, T. H. Economic value of the pest control service provided by Brazilian free-tailed bats in South-Central Texas. Frontiers in Ecology and the Environment, v. 4, no. 5, p. 238-243, 2006. https://doi.org/10.1890/15409295(2006)004[0238:EVOTPC]2.0.CO;2

Delpietro, H.; Konolsaisen, F.; Marchevsky, N.; Russo, G. Domestic cat predation on vampire bats (Desmodus-Rotundus) while foraging on goats, pigs, cows and human-beings. Applied Animal Behaviour Science, v. 39, no. 2, p.141-150, 2002 https://doi.org/10.1016/ 0168-1591(94)90134-1

Esbérard, C. E. L.; Chagas, A. S.; Luz, E. M.; Carneiro, R. A. Pesquisa com público sobre morcegos. Chiroptera Neotropical, v. 2, no. 1, p. 44-45, 1996.

Evelyn, M. Conservation of bats in suburban landscapes: Roost selection by Myotis yumanensis in a residential area in California. Biological Conservation, v. 115, no. 3, p. 463-473, 2004. https://doi.org/10.1016/ S0006-3207(03)00163-0

Gomes, S.; Helena, M.; Manfrinato, V. Bats: Perceptions of elementary school students and environmental education practices. Ciência \& Educação, v. 19, no. 4, p. 859-877, 2013. https://doi.org/10.1590/S151673132013000400006

Hayes, J. P. Temporal variation in activity of bats and the design of echolocationmonitoring studies. Journal of Mammalogy, v. 78, no. 2, p. 514-524, 1997. https://doi.org/10.2307/2404918

Hourigan, C. L.; Johnson, C.; Robson, S. K. The structure of a micro-bat community in relation to gradients of environmental variation in a tropical urban area. Urban Ecosystems, v. 9, no. 2, p. 67-82. 2006. https://doi.org/10.1007/s11252-006-7902-4

Il'in, V. Y.; Smirnov, D. G.; Yanyaeva, N. M. Effects of the anthropogenic factor on bats (Chiroptera: Vespertilionidae) in the Volga Region. Russian Journal of Ecology, v. 34, no. 2, p. 122-126, 2003. https://doi.org/ 10.1023/A:1023003215329

Jung, K.; Kaiser, S.; Böhm, S.; Nieschulze, J.; Kalko, E. K. V. Moving in three dimensions: Effects of structural complexity on occurrence and activity of insectivorous bats in managed forest stands. Journal of Applied 
Ecology, v. 49, no. 2, p. 523-531, 2012. https://doi.org/10.1111/j.1365-2664.2012. 02116.x

Kalko, K. V. Insect pursuit, prey capture and echolocation in pipistrelle bats (Microchiroptera). Animal Behaviour, v. 50, no. 4, p.861-880, 1995. https://doi.org/ 10.1016/0003-3472(95)80090-5

Kotait, I.; Takaoka, N. Y.; Panachão, M. R. I.; Sodré, M. M.; Figueiredo, A. C. C.; Schimonsky, B. V.; Andrade, A. M.; Silva, L. H. Q.; Pedro, W. A.; Fabián, M. H.; Bredt, A.; Esbérard, C.; Favoretto, S.; Carrieri, M. L. Manejo de quirópteros em áreas urbanas. São Paulo: Instituto Pasteur, 1998. (Manual técnico do Instituto Pasteur, 7). Available from: <http://portal.saude.sp.gov.br/resources/ins tituto-pasteur/pdf/manuais/manual_ 07.pdf>. Accessed on: Apr. 23, 2019.

Kuenzi, A. J.; Morrison, M. L. Temporal patterns of bat activity in Southern Arizona. Journal of Wildlife Management, v. 67, no. 1 , p. 52-64, 2003. https://doi.org/ $10.2307 / 3803061$

Kunz, T. H.; Braun de Torrez, E.; Bauer, D.; Lobova, T.; Fleming, T. H. Ecosystem services provided by bats. Annals of the New York Academy of Sciences, v. 1223, p. 1-38, 2011. https://doi.org/10.1111/j.1749-6632.2011. 06004.x

Liesener, A. L.; Smith, K. E.; Davis, R. D.; Bender, J. B.; Danila, R. N.; Neitzel, D. F.; Scheftel, J. M. Circumstances of bat encounters and knowledge of rabies among Minnesota residents submitting bats for rabies testing. Vector Borne and Zoonotic Diseases, v. 6, no. 2, p. 208-215, 2006. https://doi.org/10.1089/vbz.2006.6.208

Lu, H.; McComas, K. A.; Buttke, D. E.; Roh, S.; Wild, M. A. A One Health message about bats increases intentions to follow public health guidance on bat rabies. PlosONE, v. 11, no. 5, e0156205, 2016. https://doi.org/10.1371/ journal.pone.0156205

Mickleburgh, S. P.; Hutson, A. M.; Racey, P. A. A review of the global conservation status of bats major threats. Oryx, v. 36, p. 18-34, 2002. https://doi.org/10.1017/S00306053 01000011

Milne, D. J.; Fisher, A.; Rainey, I.; Pavey, C. R. Temporal patterns of bats in the Top End of the Northern Territory, Australia. Journal of Mammalogy, v. 86, no. 5, p. 909-920, 2005. https://doi.org/10.1644/1545-1542(2005)

86[909:TPOBIT]2.0.CO;2

Moosman, P. R.; Thomas, H. H.; Veilleux, J. P. Diet of the widespread insectivorous bats Eptesicus fuscus and Myotis lucifugus relative to climate and richness of bat communities. Journal of Mammalogy, v. 93, no. 2, p. 491496, 2012. https://doi.org/10.1644/11MAMM-A-274.1

Moran, D.; Juliao, P.; Alvarez, D.; Lindblade, K. A.; Ellison, J. A.; Gilbert, A. T.; Recuenco, S. Knowledge, attitudes and practices regarding rabies and exposure to bats in two rural communities in Guatemala. BMC Research Notes, 8:955, 2015. https://doi.org/ 10.1186/s13104-014-0955-1

Nogueira, M. R.; Lima, I. P.; Moratelli, R.; Tavares, V. D. C.; Gregorin, R.; Peracchi, A. L. Checklist of Brazilian bats, with comments on original records. Check List, v. 10, no. 4, p. 808-821, 2014. https://doi.org/10.15560/ 10.4 .808

Novaes, R. R. M.; Nobre, C. C. Dieta de Artibeus lituratus (Olfers, 1818) em área urbana na Cidade do Rio de Janeiro: frugivoria e novo registro de folivoria. Chiroptera Neotropical, v. 15, p. 487-493, 2009.

Pacheco, S. M.; Sodré, M.; Gama, A. R.; Bredt, A.; Sanches, E. M. C.; Marques, R. V.; Guimarães, M. M.; Bianconi, G. Morcegos urbanos: status do conhecimento e plano de ação para a conservação no Brasil. Chiroptera Neotropical, v. 16 , no. 1, p. 629647, 2010.

Phillips, S.; Coburn, D.; James, R. An observation of cat predation upon an eastern blossom bat Syconycteris australis. Australian Mammalogy, v. 23, no. 1, p. 5758, 2001. https://doi.org/10.1071/AM01057

Prokop, P.; Tunnicliffe, S. D. "Disgusting" animals: Primary school children's attitudes and myths of bats and spiders. Eurasia Journal of Mathematics, Science and Technology Education, v. 4, no. 2, p. 87-97, 2008. https://doi.org/10.12973/ejmste/ 75309

Reis, N. R.; Lima, I. P.; Peracchi, A. L. Morcegos (Chiroptera) da área urbana de Londrina, Paraná, Brasil. Revista Brasileira de Zoologia, v. 19, no. 3, p. 739-746, 2002. https://doi.org/10.1590/S0101-817520020 00300011 
Robertson, K.; Lumlertdacha, B.; Franka, R.; Petersen, B.; Bhengsri, S.; Henchaichon, S.; Rupprecht, C. E. Rabies-related knowledge and practices among persons at risk of bat exposures in Thailand. PLoS Neglected Tropical Diseases, v. 5, no. 6, e1054, 2011. https://doi.org/10.1371/journal.pntd.00010 54

Rübsamen, N.; Castell, S.; Horn, J.; Karch, A.; Ott, J. J.; Raupach-Rosin, H.; Mikolajczyk, R. T. Ebola risk perception in Germany, 2014. Emerging Infectious Diseases, v. 21, no. 6, p. 1012-1018, 2015. https://doi.org/ 10.3201/eid2106.150013

Sexton, B. N. R.; Stewart, S. C. Understanding knowledge and perceptions of bats among residents of Fort Collins, Colorado. Open-File Report, p.1-22, 2007. https://doi.org/ $10.3133 /$ ofr20071245

Souza, R.; Barros, M.; Bisaggio, E. L.; Borges, R. C. Morcegos (Mammalia, Chiroptera) em fragmentos florestais urbanos no Município de Juiz de Fora, Minas Gerais, Sudeste do Brasil. Biotropica, v. 6, no. 1, BN02206012006, 2006. https://doi.org/ 10.1590/S1676-06032006000100012
Threlfall, C. G.; Law, B.; Banks, P. B. Sensitivity of insectivorous bats to urbanization: Implications for suburban conservation planning. Biological Conservation, v. 146, no. 1 , p. 41-52, 2006. https://doi.org/ 10.1016/j.biocon.2011.11.026

Threlfall, C.; Law, B., Penman, T.; Banks, P. B. Ecological processes in urban landscapes: Mechanisms influencing the distribution and activity of insectivorous bats. Ecography, v. 34, no. 5, p. 814-826, 2011. https://doi.org/10.1111/j.1600-0587.2010. 06939.x

Woods, M.; Mcdonald, R. A.; Harris, S. Predation of wildlife by domestic cats Felis catus in Great Britain. Mammal Review, v. 33, no. 2, p. 174-188, 2003. https://doi.org/10.1046/j.1365-2907.2003. 00017.x

Zanon, C. M. V.; Reis, N. R. Bats (Mammalia, Chiroptera) in the Ponta Grossa Region, Campos Gerais, Paraná, Brazil. Revista Brasileira de Zoologia, v. 24, no. 2, p. 327 332, 2007. https://doi.org/10.1590/S010181752007000200010

License information: This is an open-access article distributed under the terms of the Creative Commons Attribution License, which permits unrestricted use, distribution, and reproduction in any medium, provided the original work is properly cited. 